\title{
Yeniden çeviride yan metinsel ögeler: Yeniden çevirmen olarak Cemil Meriç'in Balzac çevirisi üzerine bir inceleme
}

\section{Umut Can GöKDUMAN}

\begin{abstract}
APA: Gökduman, U. C. (2019). Yeniden çeviride yan metinsel ögeler: Yeniden çevirmen olarak Cemil Meriç’in Balzac çevirisi üzerine bir inceleme. RumeliDE Dil ve Edebiyat Araştırmaları Dergisi, (Ö5), 334-345. DOI: 10.29000/rumelide.606204.
\end{abstract}

$\ddot{O} \mathbf{z}$

Bu makalenin amacı, aynı çevirmen tarafından yapılan bir yeniden çeviriyi yan metinler aracılığıyla incelemek ve inceleme sonucunda elde edilen verileri tartışmaya açmaktır. Yeniden çevirileri ve yeniden basımları bir etkileşim alanı olarak görmek mümkündür. Bu etkileşim alanında eski ile yeni iç içe geçmekte ve bu süreç döngüsel olarak ilerlemektedir. Yöntemsel olarak yararlanılan yan metinsel ögelerin çeviri araştırmalarına katkısı özellikle son yıllarda artış göstermiştir. Bu çalışma da, yan metinsel ögelerden yararlanarak yeniden çevrilmiş bir yapıtı incelemeyi amaç edinmiştir. Araştırma kapsamında, inceleme nesnesi olarak Cemil Meriç tarafından farklı yıllarda iki kez çevrilmiş bir yapıt ele alınmıştır. Yan metinler aracılığıyla, Meriç’in Fransız romancı Honoré de Balzac'in Splendeurs et misères des courtisanes (1838-1847) adlı yapitının 1946, 1973 ve 2019 yıllarındaki çevirileri irdelenmiştir. Söz konusu irdeleme, kitap iç kapakları, eser adları, alt bölümleri, ön söz/son söz, çevirmen dipnotları ve çeviri eleştirileri düzeyinde gerçekleştirilmiştir. İnceleme sonucunda, zaman içinde farklı yayınevlerinden basılan çevirilerde yan metinsel ögelerde değişkenlik görülmüştür. Yan metinler aracılı̆̆ıyla ele alınan yeniden çevirilerin, kazanç/kayıp, iyi/kötü gibi geleneksel ikili karşıtlıkların ötesinde birbirleriyle yer yer iç içe geçtiği ve böylelikle ilk çeviri ile yeniden çeviri arasında bir etkileşim alanı oluştuğu gözlemlenmiştir.

Anahtar kelimeler: Cemil Meriç, yan metin, yeniden çeviri, yeniden çevirmen.

\section{Paratextual elements in retranslation: A translation analysis of Balzac by Cemil Meriç as a retranslator}

\begin{abstract}
This article examines a retranslation by the same translator through paratexts and discusses the findings obtained from such examination. Retranslations and reprints can be seen as a field of interaction. The old and the new are intertwined in this field of interaction, which involves a cyclical process. The contribution of paratextual elements as a methodological tool to translation research has increased especially in recent years. This study also aims to examine a retranslated work by using paratextual elements. Within the scope of the research, a work translated twice by Cemil Meriç in different years was examined as a research object. Meriç's 1946, 1973, and 2019 translations of Splendeurs et misères des courtisanes (1838-1847) by French novelist Honoré de Balzac were examined with a focus on book covers, titles, sub-sections, prefaces/postfaces, translator's footnotes, and translation criticisms. As a result of the analysis, the paratextual elements of the translations published by different publishing houses have been found to vary over time. It has been observed that
\end{abstract}

1 Arş. Gör., Hacettepe Üniversitesi, Edebiyat Fakültesi, Mütercim-Tercümanlık Bölümü (Fransızca) (Ankara, Türkiye), umutcangokduman@gmail.com, ORCID ID: 0000-0003-0045-227X [Makale kaytt tarihi: 30.06.2019-kabul tarihi: 19.08.2019; DOI: 10.29000/rumelide.606204] 
retranslations intertwine with each other beyond traditional binary oppositions such as gain/loss and good/bad, and thus a field of interaction is built between the first translation and retranslation.

Keywords: Cemil Meriç, paratexts, retranslation, retranslator.

\title{
1.Giriş
}

Bu çalışmada, çeviribilimde özellikle son yıllarda çeşitli araştırmalara konu olan yan metinsel ögeler çerçevesiyle, aynı çevirmence yapılan bir yeniden basım/çeviri irdelenmektedir. Bu amaçla seçilen araştırma nesnesi, yan metinler ve çeviri eyleyicileri anlamında birtakım veriler sunmaktadır. Çeviri yapıtlar, çeşitli sebeplerle, zaman içinde yeniden çevrilmekte ve/veya yeniden basılmakta ve bu yeniden basımlar çeviri eleştirilerinde de yankı uyandırmaktadır. Bu makalenin çıkış sorunsalını da bu türden bir yeniden çevirinin yan metinleri oluşturmaktadır. "illk çeviriler ile yeniden çeviriler arasında bir etkileşim var mıdır?” sorunsalından hareket edilen bu çalışmada, Honoré de Balzac'in Splendeurs et misères des courtisanes (1838-1847) adlı yapıtının Cemil Meriç’in 1946, 1973 ve 2019 ylllarındaki çevirileri yan metin ögeleri aracılığıyla irdelenmektedir.

Araştırma kapsamında irdelenen Kibar Fahişelerin İhtişam ve Sefaleti adlı yapıt, çevirmenin "hem Balzac'tan yayımlanan 'son' romanıdır (1946); hem de ikinci kez yayımlanma imkânına kavuşan 'tek' romanı[dır] (1973)” (Cündioğlu, 2010, s. 174). Meriç, bu eseri Türkçeye 1946 yılında çevirmiş ve bu yapit İnkılâp Kitabevi aracılığıyla Seçme Tercümeler Serisi'nden okurla buluşmuştur. Çeviri yapıt, 1973 yılında aynı çevirmen tarafından yeniden çevrilmiş ve kendisi ve/veya editör gibi farklı bir eyleyici tarafından yapılan çeşitli müdahalelerle, kitabın adı değiştirilerek bu kez Ötüken Yayınevi'nden İhtişam ve Sefalet-Vautrin- adıyla yeniden basılmıştır. Meriç'in Balzac'tan yaptığı bu çeviri, 2019 yılında bu kez İletişim Yayınlarından "Cemil Meriç Bütün Çevirileri” dizisinden okurla buluşmuştur. Yapılan metinsel ve yan metinsel incelemelerde 1946 basımı ile 2019 basımının çok büyük ölçüde örtüştüğü tespit edilmiştir. 1973 yılında yapılan yeniden çeviri metinsel ve yan metinsel olarak bu iki basımdan farklılıklar göstermektedir. İlgili yapıtın çeşitli yıllarda farklı çevirmenlerce yapılan yeniden çevirileri de mevcuttur ancak çalışma kapsamında bu çeviriler incelenmemiş, çalışma yalnızca Cemil Meriç’in çevirileri ile sinırlı tutulmuştur. ${ }^{2}$

Kaynak yapıtın yazarı hakkında çeşitli incelemeleri bulunan çevirmen, Balzac'ın en önemli yapıtlarından birisi olarak anılan bu romanın konusunu 1971 yılında şu ifadelerle tanıtır:

\begin{abstract}
Fahişeler'le yeni bir ülke fetheder roman. Romancının Lesage'dan beri dolaştığı bir ülke bu, misafir olarak dolaştığı bir ülke: Orospuların, hırsızların, katillerin dünyası. Fransız romancısı "Manon Lescaut”ya rağmen sokak kızının varlığından habersiz gibidir Balzac'a kadar. Yalnız romancı mı? Tarihçi, psikolog, ve sosyolog da insanlığın bu ezeli yarasına eğilmemiştir (...) Fahişeyi bütün yönleriyle inceleyen bu nefis monografi Balzac'ı romantizmin bir çok peşin hükümlerinden kurtarır (Meriç, 1971, s. 14).
\end{abstract}

Meriç aynı yazardan Altın Gözlü Kız (1943), Onüçler’in Romanı: Ferragus (1945) ve Otuzundaki Kadın (1945) çevirilerine de imza atmıştır. Söz konusu çevirilerinden özellikle Altın Gözlü Kız romanına yazdığı “etüd” dikkat çekmektedir. 3 Çevirmen, kaynak dizgede Balzac’a ve Balzac'ı dilimize çevirmenin önemine değinmekte, realist romanın öncüsü olarak gördüğü yazarı şu sözlerle anlatmaktadır: “...Balzac bütün

2 Balzac’tan Türkçeye yapılan çevirilerin yer aldı̆̆ı "Türkçe'de Balzac" Kaynakçası için bkz. Kalem, Karadağ \& Ebren, 1994/2007.

3 Bu ön sözün Meriç’in "ilk telif eseri” şeklinde değerlendirilmesi konusundaki bir tartışma için bkz. Cündioğlu, 2010, s. 121-133. 
eserleriyle milli kütüphanemize mal edilmedikçe, dört gözle beklenen realist roman, büyük Türk romanı, uzak bir hayal olarak kalmağa mahkûmdur" (Meriç, 1945/2017, s. 32).

Araştırma nesnesine ve önemine bu şekilde değindikten sonra, çalışma kapsamında "yeniden çevirmen" olarak değerlendirilen Cemil Meriç’in çevirmen kimliğini ön plana çıaran araştırmalar kısaca incelenerek, yeniden çeviride yöntemsel olarak yan metinsel ögelerin kullanımı değerlendirilecektir.

\title{
2.Alanyazında çevirmen Cemil Meriç
}

Türkiye'de, özellikle son yllarda yoğun bir ilgi gören Cemil Meriç’in, çevirmen olarak merkezde olduğu çalışmaların kısıtlı olduğunu söylemek mümkündür. Meriç’in farklı yönlerini/kimliklerini ele alan pek çok çalışma bulunmakla beraber bu makale kapsamında gerçekleştirilen alanyazın incelemesi, Meriç’in çevirmen yönünü merkeze alan araştırmalarla sınırlı tutulmuştur.

Çevirmen olarak Cemil Meriç’i merkeze alan en kapsamlı araştırmanın Dücane Cündioğlu'na 4 ait olduğu söylenebilir. Araştırmacı, Bir Mabed Bekçisi: Cemil Meriç - Roman ve Balzac; Şiir ve Hugo- (2006) adlı çalışmasının ön sözünde araştırma konusunu şu şekilde ifade etmiştir:

\begin{abstract}
Bu ilk kitapta, Mütercim Cemil Meriçin şimdiye değin ihmâl edilmiş en önemli eserlerini, Honoré de Balzac ve Victor Hugo'dan yaptığı manzum ve mensur çevirilerini-mümkün olabildiği kadarılyaetraflıca tasvir ve kısmen de tahlil etmeye çalıştım. Balzac tedkiklerini ve çevirilerini firsat bilip Meriç’in hem roman dünyasına ilgisini, hem de bu konudaki görüş ve eleștirilerini, yol açtığ tepkilerle birlikte ele aldım. (Bilhassa edebiyat tarihçilerimizin bu cerbezeli mevzuya hak ettiği alâkayı göstereceklerini umuyorum) (2010, s. xvi).
\end{abstract}

Cündioğlu bu araştırmada, Meriç’in Balzac’tan yaptığı tüm çevirilerini yine Meriç’in çeviri hakkındaki görüşleriyle ele alıp irdelemektedir. Daha öncesinde ayrıntılı bir biçimde incelenmeyen Meriç’in çeviri yapıtları ile ilgili açtığı bu yeni kapıdan farklı araştırmacıların da girmesini ummaktadır. Cündioğlu, Meriç’in yaptığı çeviriler dışında, yayınevlerinde kaybolan çevirilerine de şu sözlerle özellikle dikkat çekmektedir: "Temmuz ayında neşredilen Ferragusun hemen ardından basılmakta olduğunu bildiğimiz Düşes de Langeais ile (...) Bekârlar adlı iki roman- mezkur yayınevlerinde kaybolduğu içinneşrolunmamıştır” (Cündioğlu, 2010, s. 146).

Çevirmen Cemil Meriç ile ilgili çeviribilim odaklı gerçekleştirdiği "Türk Çeviri Tarihinde 'Mütercim' Cemil Meriç" adlı araştırmasında Ayşe Banu Karadağ, "Meriç'in 'görülebilirliğini'/'görülmezliğini' 'çeviribilim' çerçevesinde” irdelemiştir (2010, s. 285). Karadağ, "[h]iç kuşku yok ki her yorum çevirmenin 'gözle görülebilecek' damgasını metne taşır; çevirmenlerin önsözleri, sonsözleri, dipnotlar bunlara örnektir. Meriç’in çevirilerinde bu türden 'gözle görülür' varoluşlar oldukça fazladır” (s. 287) şeklinde bir görüş bildirmiş; "Meriç’in tüm çevirilerinde okurla 'dolaysız' ve 'samimi' bir ilişki kurarak 'görülebilir' olmayı seçtiği[ni]” belirtmiştir (s. 291). Karadağ, aynı zamanda çevirmenlerin bu "görülebilir" olma durumunu tercih etmelerinin "çağdaş çeviri yaklaşımları bağlamında büyük önem taşımakta" olduğunun ve "ancak bu şekilde çevirmen[in] onu görmezden gelmek isteyen geleneksel yaklaşımın hâkim olduğu çeviri söyleminin sınırlarını aşabil[diğinin]" altını çizmiştir (s. 291). Alanyazında çeviribilim odağıyla çevirmen Meriç’in görülebilirliği, Karadağ’ın bu araştırmasında yan metinsel ögeler üzerinden değerlendirilmiştir.

Çevirmen Meriç ile ilgili "Platonik Bir Mütercim Olarak Cemil Meriç’in Portresi” adlı bir başka araştırmada Habil Sağlam, Cemil Meriç’i "hem mesleki manada (...) hem de düşünce yordamı itibariyle" 
“mütercim” olarak tanımlamaktadır (2018, s. 229-230). Araştırmacl, Meriç’in telif ve tercüme eserleriyle ilgili şu şekilde bir değerlendirmede bulunmaktadır:

Victor Hugo'dan ya da Balzac'tan yaptığg kitap boyutundaki tercümelerin haricinde, kaleme aldığg telif eserler de baştan başa tercümelerle örülmüsstür. Cemil Meriç’in eserlerine kuş bakıșı bakan bir kişi metinlerine yayılmış onlarca farklı isimden birçok irili ufaklı çeviriyle karşılaşacaktır. Edebiyat geleneğimizde tercüme ile telif eser arasındaki sınırların muğlak oluşu gibi onun düşüncesinde de ithalat ile imalat her daim iç içe geçmiş haldedir. Üzerine fikir yürütmekte olduğu mesele etrafinda diyalog halinde olduğu düşünürlere tercümanlık eder, dolayısıyla tek yönlü bir anlatım tekniğindense sık sık farklı görüşlere söz hakkı tanıyan polifonik bir yazım tarzını benimser (2018, s. 234).

Sağlam, Meriç’in yaptığı okumaların ve telif eser üretiminin de bir çeviri şeklinde değerlendirilebileceği yorumunda bulunarak "metaforik" anlamda bir çeviriden söz ederken aynı zamanda Meriç'in çevirilerine ve çevirmen kimliğine de değinir. 5

\section{Aynı çevirmen tarafından yapılan yeniden çevirilerde yan metinsel ögeler}

Berman'a göre "bir yapıtın ilk çevirisinden sonra gerçekleştirilen her çeviri"6 (1990, s. 1) olarak tanımlanan yeniden çeviri için her ne kadar aynı metnin birden fazla çevirisine gerek duyulsa da bu çevirilerin farklı çevirmenlerce yapılması koşulunun olmadı̆̆ı ifade edilebilir. Nitekim yeniden çeviriler bazı durumlarda aynı çevirmen tarafından farklı zamanlarda yapılmaktadır. Revizyon ise yeniden çeviri için ilk adım olarak değerlendirilerek, önceki çevirilerdeki genel yapının ve tonun genel olarak korunarak mevcut erek metinde değişiklikler yapılması şeklinde tanımlanmaktadır (krş. Vanderschelden, 2000). Yeniden çeviri ve revizyon arasındaki ayrımın "belirsiz" olduğunu ifade eden araştırmacılar yeniden basımları yeniden çevirilere birer alternatif olarak görmektedir (Paloposki \& Koskinen, 2010). Yeniden çeviri gibi karmaşık bir olgu çerçevesinde, bu "belirsiz" alandan hareketle, çalışma kapsamında, Cemil Meriç’in ilk olarak 1946 yılında, ardından düzenlenmiş baskı olarak 1973 yılında yayımlanan çevirileri yeniden basımın/revizyonun7 da yeniden çeviri bağlamında ele alındığı düşünülerek incelenmektedir. ${ }^{8}$

Alanyazında aynı çevirmence yapılan yeniden çevirilerle ilgili çeşitli araştırmalar mevcuttur. Örneğin Paloposki ve Koskinen, aynı çevirmenin aynı metni belli bir zaman aralığıyla ikinci kez çevirdiği durumların olduğunu belirtmekte ve örnek olarak Seven Brothers'ın Almancaya yapılan bazı çevirileri ile ilgili Kujamäki'nin 1998 yılındaki Deutsche Stimmen der Sieben Brüder adlı çalışmasına göndermede bulunmaktadır (2010, s. 48). Bir başka çalışmada, Lei Feng, çevirmenin daha önce çevirdiği metni yeniden çevirdiği bir örnek olarak 1944 yılında Lei Fu'nun Honoré de Balzac'ın romanı Le Père Goriot'un çevirisini göstermektedir. Çevirmen, kendi çevirisinden altı yıl sonra ilk çevirisinin "esnek olmadığını ve yeterince akıcı, düzgün olmadığını [ifade ederek] bu çeviride orijinaldeki ahenk ile üslûbun kaybolmuş olduğunu [düşünmüş]" (Fu'dan aktaran Feng, 2014) ve ilk çevirisinden hoşnut olmadığının da altını çizerek bir yeniden çeviri yapmıştır (Feng, 2014, s. 70).

$\mathrm{Bu}$ çalışma ekseninde, “ilk çeviriler ile yeniden çeviriler arasında bir etkileşim var mı?” sorusunu yanıtlamak için araştırma yöntemi olarak çeviribilimde yan metinlerden yararlanılmıştır. Yan metin ögelerinin incelenmesi gerek Türkiye'de gerekse dünyada son yllarda çeviribilimde pek çok araştırmacının ilgisini çeken bir alan olmuştur. Yan metinler aracılığıyla çevirilerin incelenmesi metin

5 Bu araştırmalar dışında çevirmen olarak Cemil Meriç’i “Doğu kültürü aktarımcısı” olarak ele alan bir çalışma için bkz. Mercan, 2006.

Aksi belirtilmedikce makaledeki ceviriler tarafımdan yapılmıstır.

Revizyon/gözden geçirme konusunda ayrıca bkz. Birkan Baydan, 2011; Mossop, 2011.

Yeniden basımların yeniden çeviri kavramı çerçevesinde değerlendirildiği bir araştırma için bkz. Gökduman, 2019. 
Paratextual elements in retranslation: A translation analysis of Balzac by Cemil Meriç as a retranslator / U. C. Gökduman (p. 334-345)

içinde görünenden ziyade görünmeyen ögelerin de yüzeye çıkmasına olanak tanımakta, böylece çeviri metin incelemelerine farklı veriler sunmaktadır. Yan metin kavramına daha önce 1981 yllında Palimpsestes adlı yapıtında değindiğini belirten Gérard Genette, Seuils (1987) adlı yapitında, yan metin (paratexte) aracılığıyla bir metnin kitap hâline geldiğini, okurlarına ve daha genel olarak kitlelere kendini o şekilde sunduğunu belirtir (krş. Genette, 1987, s. 7-8). Genette, ayrıntılı olarak yan metin ögelerine ayırdığı çalışmasının sonuç kısmında en az bu yapitındaki kadar araştırma gerektirdiğini düşündüğü ve yan metinsel özelliğinin kendisi için tartışma götürmez olduğunu belirttiği çevirileri incelemesine katmadığının altını çizerken (krş. Genette, 1987, s. 408-409), Urpo Kovala, Genette'in, belli bir kültür içinde kendine has özellikleri olan çeviri yazını göz ardı ettiğinin altını çizmektedir (1996, s. 120). Şehnaz Tahir-Gürçağlar da Genette'in görüşünü çevirinin kendisinin bir yan metin olarak görülmesi şeklinde değerlendirmekte ve çeviriyi bu şekilde tanımlamanın çeviri araştırmalarına sağlayacağı katkının oldukça sınırlı olacağını belirtmekte ve çeviriyi bir "yan metin" olarak görmenin kaynak metin ve erek metin arasında hiyerarşik bir ilişki ortaya çıkaracağını vurgulamaktadır (krş. Tahir-Gürçağlar, 2002, S. 47). ${ }^{9}$ José Yuste Frias ise herhangi bir çevirinin başarılı olmasını çeviriyi çevreleyen, içine alan, çeviriye eşlik eden, çevirinin devamlılı̆̆ını sağlayan ve çeviriyi takdim eden yan metin ögelerine bağlayarak yan metinlerin önemini vurgulamaktadır (2010, s. 311). Bu bilgilerle birlikte yan metinlerin, yeniden çevirilerde de önemli olduğunun altını çizmek yerinde olacaktır. Yan metin ögeleri farklı zamanlarda ortaya çıabildiği gibi yine farklı zamanlarda, yazarın ya da farklı bir kişinin müdahalesiyle ya da zamanın aşındırıcı etkisiyle kısmen ya da tamamen ortadan kaybolabilir (krş. Genette, 1987, s. 12). O hâlde yeniden çevirilerde de yan metin ögelerinde değişikliklerin meydana gelebileceği söylenebilir. Genette yan metnin iç yan metin (épitexte) ve dış yan metin (péritexte) ögelerinden oluştuğunu şu şekilde formüle eder: "Yan metin= iç yan metin+dış yan metin" (1987, s. 11). Bu arka plandan hareketle çalışma kapsamında, dış kapak, iç kapak, ön söz/son söz, bölüm başlıkları ve dipnotlar iç yan metin ögeleri olarak incelenirken; çeviri eleştirileri dış yan metin ögesi bağlamında incelenmektedir. ${ }^{10}$

\section{Yan metin incelemeleri ile ilgili bulgular}

\subsection{Kitap dış kapakları, iç kapakları}

1946 baskısı 471, 1973 baskısı 547 ve 2019 baskısı 540 sayfadan oluşan çevirilerin dış kapakları11 incelendiğinde ilk olarak kitap adlarında bir değişiklik olduğu dikkat çekmektedir. 1946 yllında Kibar Fahişelerin İhtişam ve Sefaleti olan çeviri yapıtın adı 1973 yılında İhtişam ve Sefalet Vautrin şeklinde değişikliğe uğramıştır. ${ }^{12} 2019$ yılında ise 1946'daki kitap başlığına geri dönülmüştür. ${ }^{13}$

İç kapaklar incelendiğinde "Türkçeye çeviren: Cemil Meriç" (1946); "Tercüme: Cemil Meriç" (1973); "Çeviren: Cemil Meriç"/"Yayına hazırlayan: Mahmut Ali Meriç" (2019) şeklinde ifadeler yer almaktadır. Çevirmenin isminin gerek 1946 gerekse 1973 çevirilerinde yazarla hemen hemen aynı büyüklükte veriliyor olması Meriç’in tanınırlığı ile açıklanabilir. 1946 ve 2019 baskılarında kapakta herhangi bir resim yer almazken 1973 baskısının kapağında romanda geçen karakterler yer almaktadır. 2019 yllında her ne kadar kapakta "çevirmen" ifadesi yer almasa da çeviri yapıtın Cemil Meriç’in Bütün Çevirileri dizisinden okurla buluşuyor olması, kitap için en önemli yan metin ögelerinden birisi olarak

9 Çeviribilim odağıyla yürütülen yan metin tartışması için ayrıca bkz. Batchelor, 2018.

10 Yeniden çeviri kuramsal çerçevesiyle diller ve göstergeler arası çeviride yan metinsel ögelerin incelendiği bir araştırma için bkz. Eker-Roditakis, 2019.

11 Çeviri kitapların kapakları üzerine son dönemde yapılan bir araştırma için bkz. Mossop, 2018.

12 Cündioğlu bu ad değişikliğinin sebebiyle ilgili olarak “yayınevinin muhafazakar okur kitlesinin hassasiyetleri”ni göz önünde bulundurduğu ihtimaline değinmiştir (2010, s. 183).

13 Çeviri roman adlarının metin içi ve metin dışı ögelerle incelendiği betimleyici bir çalışma için bkz. Canlı \& Karadağ, 2019. 
değerlendirilebilir. Nitekim, okur çeviriyi henüz okumadan önce "aşina” olduğu bir ismin yaptığı çeviriyi okuyacağını kitabın kapă̆ında görüp bu çeviri hakkında bir fikir sahibi olacaktır. Bu anlamda, yan metinde Meriç’in çevirilerinin önemi vurgulanmaktadır. 2019 yllında çevirmen dışında farklı bir eyleyici de sürece dâhil olarak, kitap iç kapağında "görünür" hâle gelmiştir. Bu isim, Cemil Meriç’in İletişim Yayınlarından okurla buluşan çeviri ve telif yapıtlarında "yayına hazırlayan” olarak karşımıza çıan Mahmut Ali Meriç’tir. 2019 kitap iç kapağında “[k]itap yayına hazırlanırken Cemil Meriç'in özgün çevirisine sadık kalınmıştır. Aksi belirtilmedikçe bütün dipnotlar Cemil Meriç’e aittir” (Meriç, 2019, s. 6) şeklinde bir ibare yer almaktadır. Burada sözü edilen "özgün çeviri”, 1973 yılındaki çeviri değil 1946 yllındaki çeviridir ve Meriç’in ilk çevirisine geri dönüş söz konusudur.

\subsection{Kitap bölüm başlıkları}

Bölüm başlıkları da kitap adları gibi yıllara göre farklılıklar göstermektedir. Kitap bölüm başlıkları şu şekilde tablolaştırılabilir:

Tablo 1. Kitap bölüm başlıkları

\begin{tabular}{|l|l|l|}
\hline $\begin{array}{l}\text { EM1 (1946)-EM3 (2019) } \\
\text { Kibar Fahişelerin Ihtişam ve } \\
\text { Sefaleti }\end{array}$ & $\begin{array}{l}\text { EM2 (1973) } \\
\text { İhtişam ve Sefalet- } \\
\text { Vautrin }\end{array}$ & $\begin{array}{l}\text { KM (1855)14 } \\
\text { Splendeurs et misères des } \\
\text { courtisanes }\end{array}$ \\
\hline 1. Fahişeler Nasıl Sever? & 1.Yosmalar Sevince & 1.Esther heureuse \\
\hline 2. İhtiyatkârlıkta Aşk Neye Malolur? & 2. İhtiyarlıkta Aşk & $\begin{array}{l}\text { 2. À combien l'amour revient aux } \\
\text { viellards }\end{array}$ \\
\hline 3. Fena Yolların Sonu Nereye Varır? & 3. Kötü Yolların Sonu & 3. Où mènent les mauvais chemins \\
\hline 4. Vautrin'in Son Görünüşü & 4. Votren'in Son Görünüşü & 4. La dernière incarnation de Vautrin \\
\hline
\end{tabular}

Bu tablodan hareketle, farklı yıllardaki çevirilerde bölüm başlıklarının hem benzerlik hem de farklılık gösterdiği söylenebilir. Bölüm başlıklarında da kitap adında olduğu gibi "fahişe" sözcü̆ünün kullanılmadığı, onun yerine "yosma" sözcüğünün yer aldığı görülmektedir. ${ }^{15}$ Bu durumu Sağlam, Meriç'in "Balzac'ın romanına seçtiği başlık üzerinde tasarrufta bulunma hakkını bir mütercim olarak kendisinde bulması veya argo ifadeleri çevirmemeyi tercih etmesi, doğrudan doğruya benimsediği platonik tercüme anlayışıyla ilgilidir" (2018, s. 243) şeklinde açıllamaktadır. Dikkat çeken başka bir nokta 1973 yeniden çevirisinde kaynak metinde olduğu gibi "ihtiyarlık" sözcüğü kullanılırken ilk çeviride "ihtiyatkârlık" sözcüğünün kullanılmış olmasıdır. Burada yer alan alt başlıkların, diğer yan metin ögelerinde olduğu gibi doğrudan Meriç tarafından mı yoksa yayına hazırlayan(lar) tarafından mı bu şekilde aktarıldığına dair herhangi bir bilgi notu bulunmadığından söz konusu tasarrufun hangi çeviri eyleyicisine ait olduğu kesin olarak bilinmemektedir.

\section{3.Ön söz/Son söz}

1946 yılında "Eserin Kahramanları" başlığıyla kaleme alınan 15 sayfalık bir ön söz ya da Cemil Meriç’in ifadesiyle bir "etüd" yer alırken, 1973 yılında aynı "etüd" kısaltılarak "Notlar" başlığıyla son söz şeklinde kitabın arka kısmında yer almıştır. 1946 ve 1973 çevirileri arasında kurulan bir diğer bağlantı ise Cemil

\footnotetext{
14 Fransızca başlıklar Türkçeye birebir olarak şu şekilde çevrilebilir: Kibar Fahişelerin İhtişam ve Sefaleti, 1)Esther mutlu; 2)İhtiyarlıkta aşk ne kadara gelir?; 3)Kötü yollar nereye çıkar?; 4)Vautrin’in son enkarnasyonu.

15 "Cemil Meriç 1942'de bir vesileyle Balzac'ın bu romanından söz ederken kitabın adını Aşüftelerin İhtişam ve Sefaleti şeklinde Türkçeleştirmiştir” (Cündioğlu, 2010, s. 183).
} 
Paratextual elements in retranslation: A translation analysis of Balzac by Cemil Meriç as a retranslator / U. C. Gökduman (p. 334-345)

Meriç’in “Okuyacağınız Kitap” başlıklı ön sözüdür. Bu ön sözde Meriç, özellikle eserin isminin değişmesiyle ilgili şu şekilde bir yorumda bulunarak isim değişikliğinin sebebini açıklamıştır:

Eserin belki de en tenkid edilecek tarafı: İsmi. Birinci bölümde (Yosmalar Sevince) Torpil'den başka fahişe yok. İkinci bölümde (İhtiyarlıkta Aşk) görünüp kaybolan bir iki sahne artisti fuhşun yegâne temsilcileri. Üçüncü ve dördüncü bölümlerde ise ne Torpil var, ne ötekiler. (...) Vâkıa eserin orjinal fransızca- adı, "Fahişelerin İhtişam ve Sefaleti”... Fakat yukarıda da belirtildiği gibi fahişeler eserin sadece iki bölümünde mevcut... Ancak bu iki bölümde de "fahişelik”ten ziyade aşk bahis mevzuudur. Eserde işlenen esas fikir fahişelerin, kanun dışı kimselerin, polisin ve adliyenin ihtişam ve sefaleti... Bu sebeple eserin geniş ölçüde gözden geçirilmiş ve düzeltilmiş bu ikinci baskısı için "İhtişam ve Sefalet" ismini uygun gördüm. Ve ikinci bir isim olarak da, bir numaralı kahramana izafeten Votren(Vautrin)i seçtim (Meriç, 1973, s. 6-8).

Meriç, 1973 yllındaki isim değişikliğini bu şekilde gerekçelendirerek, bu baskının "gözden geçirilmiş" ve "düzeltilmiş” ikinci baskı olduğunu belirtmektedir. Söz konusu gözden geçirme ve düzeltmelerin, zaman içerisinde gerek sözcük düzeyindeki değişikliklerle gerekse değişen çevirmen kararları ile birlikte düşünüldüğünde bir yeniden çeviriye işaret ettiği söylenebilir. Çevirmen ayrıca 1973 yılında son söze "[e]serin belli başlı kahramanlarını tanımak isteyen okuyucu, kitabın sonundaki notlara baş vurabilir" (Meriç, 1973, s. 8) şeklinde düştüğü notla okuru yönlendirmektedir. Balzac’tan yaptığı diğer iki çevirinin ön sözlerinde eserlerin çevirileri üzerine bilgi notları düşen Meriç, bu çevirisinde çevirisi hakkındaki yorumları için dipnotlar eklemiştir.

\section{4.Çevirmen dipnotları}

Cemil Meriç çevirileriyle ilgili çeviri eleştirilerinde odak noktasının çevirmen dipnotları olduğu görülmektedir. Bu bilgiden hareketle, yapılan incelemede 1946 ve 1973 çevirilerindeki dipnotların ne derece örtüştüğü konusunda elde edilen bulgulara göre 1946 yllında çevirmen tarafından 124 adet dipnot kullanılırken, 1973 yılında 45 adet dipnot kullanıldığı tespit edilmiştir. 1946 yılındaki dipnotlarla birebir örtüşen 2019 baskısında ise ek olarak 1 adet yayına hazırlayan dipnotu bulunmaktadır. Mahmut Ali Meriç tarafından düşülen bu dipnot, çevirmen dipnotunun altında, metinlerarası bir unsura dikkat çeken bir ekleme şeklindedir (bkz. s. 126).

1946 yllında çevirmen dipnotu olarak yer alan dipnotların bir bölümü 1973 yılındaki dipnottan alınarak metin içine yerleştirilmiştir. Her ne kadar yeniden çeviride dipnot sayısında belirgin bir azalma söz konusuysa da 1946 yllında olmayı 1973 yılında bulunan dipnotlar da söz konusudur. Dipnotlar, arka plan bilgisi, yabancı sözcükler için açıklama ve çevirmen kararları şeklinde üç başlık altında ele alınmış ve tablolaştırılmıştır: 16

Tablo 2. Dipnotlar

\begin{tabular}{|l|l|l|}
\hline Dipnot alt başlıkları & EM1 (1946)-EM3 (2019) & EM2 (1973) \\
\hline Arka plan bilgisi & $\% 63$ & $\% 54$ \\
\hline Yabancı sözcükler için açılama & $\% 27$ & $\% 38$ \\
\hline Çevirmen kararları & $\% 10$ & $\% 8$ \\
\hline
\end{tabular}

Arka plan bilgisi, bir yapıta, kişiye ya da tarihi bir olaya yapılan göndermelerden oluşmaktadır. Örneğin çevirmen bir dipnotta kendi yaptığı bir çeviriye göndermede bulunmaktadır: "Bu zat [Pamiers piskopos

16 Farklı bir örnekçe üzerinden, çalışmasının bir bölümünde çevirmen notlarını “Dile' İlişkin Çevirmen Notları”, “Metinlerarası Özelliklere' İlişkin Çevirmen Notları”, "Sosyokültürrel Arka Plana İlişkin Çevirmen Notları" şeklinde inceleyen bir araştırma için bkz. Taş, 2018. 
vekili] hakkında bilgi edinmek isteyen okuyucular, Ferragus ve Düşes de Langeais isimli tercümelerimize müracaat edebilirler" (Meriç, 1946, s. 95; Meriç, 2019, s. 110). Yabancı sözcükler için açıklamaların büyük bir bölümünü Fransızca sözcükler oluştururken, Latince, Arapça ve İngilizce sözcükler için de açıklamalar mevcuttur. Fransızca bir sözcük için yapılan araştırma ve açıklama için şöyle bir dipnot yer almaktadır: "Balzac bochettine kelimesini kullanıyor ki, ne Akademi'nin, ne Littré'nin lügatlerinde ne de Larousse Pour Tous'da bulabildik. Marpuç olduğu karine ile anlaşllyor" (Meriç, 1946, s. 64 ; Meriç, 2019, s. 75). Çevirmen kararları altında ise çevirmenin yaptığı tercihler ve karşlaştığı güçlükleri aşmak için yararlandığı yöntemler yer almaktadır. Çevirmen Meriç’in çeviride aldığı kararları gerekçelendirmesi anlamında önem taşıyan bu son kategoride ise şu şekilde bir örnek yer almaktadır: "Mütercim, senet, sepet, tahvilât poliçe meselelerinde tam manasıyla cahil olduğunu utanarak itiraf eder. Romanın kanevasında [taslağında] mühim yer tutmayan bu bahiste bir hayli hatalara düşmüş olması kuvvetle muhtemeldir” (Meriç, 1946, s. 144 ; Meriç, 2019, s. 164).

Dipnot sayıları 1973 yılında genel olarak azalmakla beraber yabancı sözcükler için açılama kategorisinde bir artış görülmüş̧ür. Bunun dışında, 1973 yılında yalnızca çıkarmalar değil eklemeler de söz konusu olmuştur. Örneğin Meriç’in, "Türk argosuyla karşlamamıza imkân olmayan bazı misalleri atlamak zorunda kalıyoruz. Bu mecburî makaslamada cehlimizin de büyük payı olduğu muhakkaktır (...)” (Meriç, 1946, s. 378 ; Meriç, 2019, s. 434) şeklinde bir dipnotla çıkardığını belirttiği kısım kaynak metinde 564 sözcüklük bir kısma denk gelmektedir. 1973’te ise bu kısma birtakım eklemeler yapılmış ve çıkarılan kısım 414 sözcüğe düşmüştür.

2019 dipnotları, 1946 yılı ile aynı kalmakla birlikte, yayına hazırlayanın müdahalesiyle çevirmen dipnotları korunmuş ancak yer yer metin içinde köşeli parantezle "eski" sözcükler "yeni” karşılıklarıyla birlikte verilmiştir. "Tariz [iğneleme]" (Meriç, 2019, s. 28), "hacir [kısıt] (Meriç, 2019, s. 113), "memnu [yasak] (Meriç, 2019, s. 256) bunlara birkaç örnek olarak verilebilir.

$\mathrm{Bu}$ makale her ne kadar yan metinsel ögelerin incelenmesi ile sınırlı tutulmuşsa da dipnotlardaki azalmanın metin içinde herhangi bir karşılığı olup olmadığı sorusundan hareketle yapılan metin incelemesi sonucunda metin içinde yer yer 1946 yılında olmayan unsurların bulunduğu tespit edilmiştir:

Tablo 3. Metin İnceleme Örnek 1

\begin{tabular}{|l|l|}
\hline EM1 (1946)-EM3 (2019) & - \\
\hline EM2 (1973) & $\begin{array}{l}\text { "Müdür gardiyana: } \\
\text {-Sanık burada kalsın, dedi. Oğlunun saçlarından bir iki tutam kesip verin } \\
\text { kendisine" (s. 431). }\end{array}$ \\
\hline KM (1855) & $\begin{array}{l}\text { "Le directeur dit au surveillant de laisser le prévenu dans cette cellule, et de } \\
\text { couper quelques mèches de cheveux pour le prétendu père sur la tête du fils, avant } \\
\text { qu'on ne vint enlever le corps" (s. 840). }\end{array}$ \\
\hline
\end{tabular}

Bu ilk örnekte, kaynak metinde yer alan bir ifadenin 1946/2019 yllarında çevrilmediği ancak 1973’te çevrildiği görülmektedir.

Tablo 4. Metin İnceleme Örnek 2

\begin{tabular}{|l|l|}
\hline EM1 (1946)-EM3 (2019) & $\begin{array}{l}\text { “Carlos gülümseyerek: } \\
\text { 'Incedo per ignes!' dedi... 'Mesleğim bu...” (s. 105). }\end{array}$ \\
\hline EM2 (1973) & "Incedo per ignes (ateş içinde ilerlerim), dedi. Mesleğim bu” (s. 89). \\
\hline KM (1855) & “Incedo per ignes! répondit le faux prêtre en souriant, c’est mon métier” (s. 169). \\
\hline
\end{tabular}


Paratextual elements in retranslation: A translation analysis of Balzac by Cemil Meriç as a retranslator / U. C. Gökduman (p. 334-345)

Bu örnekte ise 1946/2019 çevirilerinde herhangi bir açılama bulunmayan Latince ifade için 1973 yılında metinde parantez içinde bir açılkama bulunmaktadır. ${ }^{17}$

\section{5.Çeviri eleştirileri}

Aynı zamanda bir çeviri eleştirmeni olan Cemil Meriç’in Balzac’tan yaptığı bu çeviri hakkında kaleme alınan sınırlı sayıda çeviri eleştirisi bulunmaktadır. İncelenen yapıtla ilgili en ayrıntılı eleştirilerin Cündioğlu tarafından yapıldığı söylenebilir. Araştırmacı, Meriç’in Balzac'tan yaptığı diğer çevirilere de değinerek şu şekilde bir yorumda bulunmaktadır:

(...) Ferraguste, yeri geldiğinde cehaletini itiraf eden, Otuzundaki Kadında, mehazlara sadakat göstermekle birlikte pekâlâ yanılmış olma ihtimalinin de bulunduğunu açıkça belirten, hatta çevirisinde zorlandığı bir kelimenin Türkçe'de karşılığını bilmediğini söylemekten çekinmeyen genç mütercim, Kibar Fahişelerin İhtişam ve Sefaletinde de okurunu şaşırtmayı sürdürecek ve dokuz ay gibi bir sürede, üstelik göz kamaştırıcı bir başarıyla tercüme etmiş olmasına rağmen, yeri geldikçe okuru karşısında kendi zaaf ve yetersizliklerini dile getirmeyi bir vazife telakki edecektir (Cündioğlu, 2010, s. 174).

Oldukça başarılı bulunan bu çeviri hakkındaki eleştiri, yapıtın Meriç tarafından 1946'da yapılan ilk çevirisine yöneliktir. Meriç’in verdiği dipnotlar üzerinden gerçekleştirdiği okuma sonucunda bu dipnotların "çeviri tarihi açısından nadir değil, ender olarak vasıflandırılması gerektiğini” (s. 175), çevirmenin hem "ticarı̂" hem de "hukukî" terimlerde "ciddi tercüme sıkıntıları yaşadı̆̆ı"nı (s. 175) ve bu "yetersizliğini çeşitli vesilelerle itiraf etmekle kalma[yıp], bu konuda elinden gelen çabayı ortaya koyduktan sonra yine de hata yapma ihtimali karşısında okurunu uyarmayı sürdür[düğünü]” (s. 176) belirtmektedir. Cündioğlu, Meriç’in "anlam kaybını asgariye indirmek için Türkçe’nin sınırlarını mümkün olduğunca zorladığı gibi, bazen de kelime-be-kelime çeviri yapmayı daha uygun bul[duğunu]” (s. 177) ve çevirmenin aynı zamanda "münasebet düşürdükçe 'münekkid' kimliğiyle de ortaya çıkarak bazı önemli isimleri de eleştir[diğini]” belirtir (s. 178). 1946 çevirisiyle ilgili bu eleştirilerin genel olarak olumlu olduğu görülmektedir.

Sağlam ise çevirmenin "bu romanda sıklıkla kullanılan argo deyişleri Balzac'a yakıştırama[yıp], bunların Türkçeye aktarılamayacağını öne sürerek söz konusu ifadeleri ‘makasla[dığını]”'(2018, s. 243) belirtir. Çeviri sırasında yapılan çıkarma işlemi çevirmen tarafından dipnotlarda gerekçelendirilmektedir.

1973 yılında yapılan yeniden çeviri ile ilgili çeviri eleştirileri incelendiğinde Vahap Kaba, çeviriyle aynı yıl çıkan yazısında "Ötüken Yayınevi üstad Cemil Meriç’in kalemiyle bu değerli romanı bize kazandırmış bulunuyor" (1973, s. 22) yorumunda bulunmuştur. Turgut Güler ise Kitap Köşesi’nde çevirmen olarak Meriç'e duyduğu güveni ve Meriç'in kaleminin ne denli güçlü olduğunu ifade etmiştir:

Tercüme eserlerde, yazarın büyüklüğü kadar, tercüme edenin üzerimizde sağlayacağı emniyet de mühimdir. Çünkü, aslından okuma imkânımız yoksa, yazıldığı dilden anlamıyorsak, okuyacağımız eserde bütün iyi niyetimizi tercüme edene teslim ediyoruz demektir. Balzac, sadece Fransa'nın değil, bütün dünyanın hayran olduğu bir sanatkâr. O’nu dilimize çeviren de Cemil Meriç gibi yüksek bir kalem olunca, ilk sayfalardan itibaren içimiz güvenle doluyor. İki dil arasında kurulan köprü öyle sağlam bir geçiş ki, Balzac’ın “ïhtişam ve Sefalet”i sanki Türk diliyle yazdığını sanıyoruz (1973, s. 39).

Cündioğlu'nun 1946 çevirisindeki olumlu eleştirileri 1973 yllında farklılık göstermektedir. İlk olarak bu yeniden basım altında yatan sebepleri, ardından Cemil Meriç’in yeniden basımda/çeviride aldığı kararların sebeplerini sorgulamaktadır. Cündioğlu, bu yeniden basımın "sağcı bir yayınevi tarafından 
neşredilmesi” (s. 183) ve/veya "mütercimin (...) ikinci baskıda metnin sayfa sayısını düşürmek maksadıyla hareket etmesi” (s. 188) gibi sebeplerle gerçekleşmiş olabileceğini belirtmekte ancak bunlardan herhangi birinin tek sebep olmadığını düşünmekte ve 1973 baskısı ile ilgili bu kez olumsuz bir görüş bildirmektedir:

(...) dokuz ay boyunca tercümenin ilk baskısına verilen emeklerin, en nihayet bir dokuz ay daha harcanarak ikinci baskıda heba edildiğini söylemek zorunda kalacağız. Çünkü ikinci dokuz ay, ilkinin aksine tercümeyi budamak ve şayet bir meziyet telâkki edilirse, özel isimleri Türkçe okunuşlarıyla yazıp binbir emekle kaydedilen dipnotları çıkarmaktan ibarettir (2010, s. 181).

Cündioğlu aynı zamanda Meriç’in kullandığı dipnotların çıkarıldığının da altını çizmektedir:

(...)çevirinin ikinci kez yayımlanması uğruna, kendisinden beklenilmeyecek tasarruflarda bulunarak eserin sadece dilini ve üslûbunu değiştirmekle/sadeleştirmekle kalmamış, dipnotların önemli bir kısmını da bu baskıdan çıkarmıştır. Ayrıca, -muhtemelen yayıncının telkinleriyle-yeni okur kitlesini dikkate alarak çevirinin adını değiştirdiği gibi, romanın konusunu bile okurun beklentileriyle çatışmayacak şekilde tasvir etmekten kaçınmamıştır (2010, s. 180).

Araştırmacının 1973 çevirisi ile ilgili eleştirileri, oldukça başarılı bulduğu diğer tüm Meriç çevirilerinden farklllık göstermektedir.

\section{Tartışma ve sonuç}

Bu çalışmada aynı çevirmen tarafından yapılan bir yeniden çeviride, yan metin ögeleri arasında ne tür bir etkileşim olduğu sorunsalından hareketle, farklı yıllardaki yeniden çeviriler mercek altına alınmıştır. Meriç"in 1973 yeniden çevirisinde yaptığı "düzenleme" ya da "gözden geçirme" şeklindeki değişiklikler yeniden çeviri kavramı dâhilinde değerlendirilmiştir. Nitekim, çevirmen aynı kalmakla birlikte zaman içinde sosyo-ekonomik koşulların çevirmen kararlarına yansımış olabileceği düşünülmektedir. 2019 yılında yapılan çeviride, 1973 yılındaki yeniden çeviri dikkate alınmamış, doğrudan 1943 baskısına bir dönüş gerçekleşmiştir.

Yeniden çeviri olgusunun sebepleri, bir örnek incelemesi üzerinden sorgulanmış ve farklı yıllarda aynı çevirmence yapılan çevirilerde yer yer örtüşmeler yer yer ise farklılıklar gözlemlenmiştir. Çeviri yapıt ele alındığında, ilk karşılaşılan yan metin ögelerinden olan kitap kapaklarının gerek çevirmenin görünürlüğünü gerekse kitabın başlığını yansıtması bakımından önemli olduğu görülmüştür. İncelenen kitap kapaklarında farklı yıllardaki çevirilerde Meriç'e yapılan vurgu ön plana çıkmış ancak özellikle 2019 yılında bu vurgu daha belirgin bir hâl almıştır. 2019 yllı iç kapağında 1946 ve 1973 ylllarında birer baskı yapıldığının belirtilmesi de yan metinlerde bir etkileşim göstergesi olarak değerlendirilmiştir. Yeniden çevirilerde yan metin ögesi olarak ön söz ve son sözün yer değiştirebileceği ve bu değişiklikle birlikte bu yan metinsel ögelerin uzunluklarının da değişebileceği vurgulanmıştır.

Çeviri eleştirmeni olarak Meriç’in dipnotlarının incelenmesi çeviribilim bağlamında önemli veriler sunmuştur. Dipnotlardaki azalma üzerinden getirilen eleştirilerde, çevirmen dışında çevirinin yan metinlerinin düzenlenmesinde de farklı çeviri eyleyicilerinin aktif rol aldığı/alabileceği gözlemlenmiştir. Örneğin, dipnotlar zaman zaman metin içine taşınmış, bu sebeple, yan metinlerle ilgili çeviri eleştirilerinde çevirmen dışında yayına hazırlayanın/editörün de incelenmesinin önemi ortaya çıkmıştır. Yeniden çeviri söz konusu olduğunda, birden fazla çeviri içinden "en iyi”nin seçilmesinden ziyade bu yeniden çevirilerin birbirleriyle olan ilişkilerinin göz önünde bulundurulmasının çeviribilim incelemelerinde daha zengin bilgiler sunabileceği düşünülmüştür. Yapılan incelemedeki etkileşim, aslında çevirmen ve okur arasında tek taraflı olarak gerçekleşmemiştir. Eleştirmen kimliğiyle de çeviri 
sürecine dâhil olan çevirmen Meriç, farklı yıllarda yaptığı çevirilerle zaman içinde farklı karar mekanizmaları devreye sokarak çevirisine müdahale etmiş ve çevirisini değiştirmiştir. Çevirilerde ve yan metin olarak çeviri eleştirilerinde çevirmenin "görülebilir" olması ilk çeviride olduğu gibi sonraki çevirilerde de ön plana çıkmıştır. Eleştirilerin, aynı çevirmen tarafından yapılan yeniden çevirilerde de etkili olduğu söylenebilir. Farklı yıllarda yapılan yeniden çevirilerde iyi/kötü; kazanç/kayıp gibi geleneksel ikili karşıtlıklarla beraber, yeniden çeviri metin düzeyinde incelendiğinde farklı "kazanç"ların da olduğu görülmüştür. Yeniden çeviride, çevirmen dışında edebiyat eleştirmeni, yayına hazırlayan gibi eyleyiciler de süreçte aktif rol oynamaktadır. Öyle ki 2019 yılında seriden çıkan diğer çevirilerde olduğu gibi Meriç’in 1940'lı yıllarda yaptığı çevirilerin kullanılması bu türden bir eyleyici aracılığıyla gerçekleştirilmiştir. Çeviri eyleyicilerinden çevirmen aynı kalsa da bu eyleyiciyle birlikte yayınevlerinin kararları zaman içinde farklılık göstermiştir. O hâlde yeniden çeviride, edebiyat eleştirmeni ya da yayına hazırlayan gibi çevirmen dışındaki eyleyicilerin üzerinde durulmasının önem kazandığı ifade edilebilir. Meriç'in "kayıp" çevirileri örneğinde olduğu gibi çeviri tarihi araştırmaları bağlamında çevrilen ya da çevrilmeyen yapıtlar kadar çevrilip de kaybolan yapıtların da araştırmacılar tarafından keşfedilmesinin ve incelenmesinin önemli olduğu düşünülmektedir. Son olarak, aynı çevirmen tarafından yapılan yeniden çeviriler yan metinler çerçevesiyle değerlendirildiğinde, yeniden çeviride dilde her zaman en “yeni”nin ya da en “sade”nin aranmadığı görülmüştür. Öyle ki, bu incelemede 1940'lardaki çeviriye geri dönülmüş̧ür. Bu durum da aslında Türkiye özelinde Balzac’tan yapılan bir çeviri bağlamında yeniden çevirinin farklı sebeplere dayandığının bir göstergesi olarak düşünülebilir.

\section{Kaynakça}

Balzac, H. (1855). Splendeurs et misères des courtisanes. Paris: Alexandre Houssiaux.

Balzac, H. (1946). Kibar fahişelerin ihtişam ve sefaleti (C. Meriç, Çev.). İstanbul: İnkılâp Kitabevi.

Balzac, H. (1973). İhtişam ve sefalet- Vautrin (C. Meriç, Çev.). İstanbul: Ötüken Yayınevi.

Balzac, H. (2019). Kibar fahişelerin ihtişam ve sefaleti (C. Meriç, Çev.). İstanbul: İletişim Yayınları.

Batchelor, K. (2018). Translation and paratexts. New York: Routledge.

Berman, A. (1990). La retraduction comme espace de la traduction. Palimpsestes, 4, 1-7.

Birkan Baydan, E. (2011). Editing as rewriting. İ. Ü. Çeviribilim Dergisi, 3(2), 53-78.

Canlı, G. \& Karadağ, A. B. (2019). William Faulkner'ın Sanctuary romanının Türkçede nasıl adlandırıldığı üzerine betimleyici bir çalışma. RumeliDE Dil ve Edebiyat Araştırmaları Dergisi, $14,454-468$.

Cündioğlu, D. (2006). Bir mabed işçisi: Cemil Meriç-Bir Cumhuriyet aydının serencâmı-. İstanbul: Etkileşim Yayınları.

Cündioğlu, D. (2006/2010). Bir mabed bekçisi: Cemil Meriç-Roman ve Balzac; Şïr ve Hugo-. İstanbul: Kapı Yayınları.

Cündioğlu, D. (2007). Bir mabed savaşçısı: Cemil Meriç-Bir münekkidin nârâst-. İstanbul: Etkileşim Yayınları.

Eker-Roditakis, A. (2019). Repackaging, retranslation, and intersemiotic translation: A Turkish novel in Greece. Ö. Berk Albachten \& S . Tahir Gürçağlar (Ed.), Perspectives on Retranslation Ideology, Paratexts, Methods (67-86). New York: Routledge.

Feng, L. (2014). Retranslation hypotheses revisited: A case study of two English translations of Sanguo Yanyi-the first Chinese novel. Stellenbosch Papers in Linguistics Plus, 43, 69-86.

Genette, G. (1987). Seuils. Paris: Editions du Seuil.

Gökduman, U. C. (2019). Yeniden basımlarda "diliçi çevirmen” olarak editör. S. Taş (Ed.), Çeviribilimde Araştırmalar (199-212). İstanbul: Hiperlink Yayınları. 
Güler, T. (1973). Kitap köşesi. Türk Edebiyat, 16, 38-39.

Kaba, V. (1973). Cemil Meriç’in Balzac’tan çevirdiği İhtişâm ve Sefâlet. Türk Edebiyatı, 18, 22-23.

Kalem, A., Karadă̆, B. \& Ebren, Z. (1994/2007). "Türkçe'de Balzac” kaynakçası. M. Rifat (Yay. Haz.), Honoré de Balzac Romancının Evreninden Sahneler (311-334). İstanbul: Türkiye İş Bankası Kültür Yayınları.

Karadă̆, A. B. (2010). Türk çeviri tarihinde 'mütercim' Cemil Meriç. M. E. Özcan (Yay. Haz.), VI. Ulusal Frankofoni Kongresi Geçmişten Geleceğe Türkiye’de Frankofoni (285-292). Kars: Kafkas Üniversitesi Yayınları.

Kovala, U. (1996). Translations, paratextual mediation, and ideological closure. Target. International Journal of Translation Studies, 8(1), 119-147.

Mercan, H. İ. (2006). Çevirinin kültür transferindeki rolü (Friedrich Rückert-Cemil Meriç örneğinde) (Yayımlanmamış yüksek lisans tezi). Sakarya Üniversitesi Sosyal Bilimler Enstitüsü.

Meriç, C. (1971). "Fahişeler”i okurken. Hisar, 92, 14-15.

Meriç, C. (2017). Önsöz Balzac. C. Meriç (Çev.), Ferragus (ss. 9-32). İstanbul: İletişim Yayınları.

Mossop, B. (2011). Revision. Y. Gambier \& L. van Doorslaer (Ed.), Handbook of Translation Studies (135-139). Amsterdam/Philadelphia: John Benjamins.

Mossop, B. (2018). Judging a translation by its cover. The Translator, 24(1), 1-16.

Paloposki, O. \& Koskinen, K. (2010). Reprocessing texts. The fine line between retranslating and revising. Across Languages and Cultures, 11(1), 29-49.

Sağlam, H. (2018). Platonik bir mütercim olarak Cemil Meriç’in portresi. A. Öz (Haz.), Cemil Meriç Kitabı “Bu Ülkeyi Düşünmek" (227-248). İstanbul: Zeytinburnu Belediyesi Kültür Yayınları.

Tahir-Gürçağlar, Ş. (2002). What texts don't tell: The use of paratexts in translation research. In Theo Hermans (Ed.), Crosscultural Transgressions. Research Models in Translation Studies II: Historical and Ideological Issues (44-60). Manchester: St. Jerome.

Taş, S. (2019). Çeviribilimde ikili karşıtlıkları yeniden değerlendirmek: Çevirmenin "görünürlüğü"/"görünmezliği” ve "yerlileştirme"/"yabancllaştırma”. Tarih Okulu Dergisi, 38, 94121.

Vanderschelden, I. (2000). Why retranslate the French classics? The impact of retranslation on quality. In. M. Salma-Carr (Ed.), On Translating French Literature and Film II. Amsterdam/Atlanta: Rodopi.

Yuste Frías, J. (2010). Au seuil de la traduction: la paratraduction. In T. Naaikjens (Ed.), Event or Incident/Evénement ou incident: On the Role of Translation in the Dynamics of Cultural Exhange/Du Rôle des traductions dans les processus d'échanges culturels (287-316). Bern: Peter Lang. 